\title{
Higher Vocational Civil Aviation Transportation Talent Training Strategies under the Objective of Vocational Ability Training
}

\author{
Shi Yuehong \\ Sanya Aviation \&Tourism College, Hainan Sanya, 572000, China
}

Keywords: Vocational ability; Higher vocational; Civil aviation transportation major; Personnel training

\begin{abstract}
With the internationalization of civil aviation in China, a large number of highly qualified and highly skilled personnel must be trained by civil aviation vocational colleges. Based on the goal of training vocational ability, this paper expounds the occupational standards of civil aviation transportation and puts forward cultivation strategies of civil aviation transportation talents. In face of current problems of unreasonable curriculum setup, slow updating of teaching materials and backward teaching modes in the training of civil aviation transportation personnel in higher vocational colleges, a more scientific talent training program and teaching curriculum system is designed based on "Four Major Vocational Skills". Therefore, it is necessary to introduce and train "Dual-type" teachers to innovate teaching methods and realize the integration of "teaching, learning and doing"; carry out training design and off-campus production internships in schools to provide higher vocational students more opportunities to learn through practice and constantly improve personal professional ability.
\end{abstract}

\section{Introduction}

In recent years, the rapid economic development in our country and the rise of tourism has all provided a good opportunity for the development of civil aviation industry. The demand for civil aviation transportation personnel is also on the rise. Higher vocational civil aviation college and university are the major sources of social civil aviation personnel, shouldering the important mission of civil aviation development. The 12th five-year period is an important stage for the development of civil aviation in our country. In order to fully implement the strategy of popularization and globalization, we must build highly qualified personnel with professional, multilevel and international standards. Based on this, it is of great realistic significance to study the training strategy of civil aviation transportation talents in higher vocational colleges.

\section{Vocational capacity training goals}

\subsection{National occupational standards}

Civil aviation transport enterprises have the requirements for front-line business personnel in accordance with national occupational standards, the appraisal rules issued by national human resources, social labor and social security departments. Civil aviation transport students can participate in four appraisal types, namely crew, cargo runner, passenger and civil aviation conductor, and five levels, namely, beginner, middle and high, technician, senior technician. Apart from the current five institutions directly under CAAC, no other colleges really carry out the identification work. Students have to participate in vocational skills appraisal after the internship in the third year.

\subsection{Industry occupational standards}

In civil aviation transport industry, International Air Transport Association and China Air Transport Association are two important associations, which are responsible for the uniform promulgation of business performance standards and entering positions. Business credentials are 
used to determine occupation qualifications.

\subsection{Enterprise occupational standards}

Civil aviation enterprises have strong responsibility for safety due to multiple types of work with technical complexity and so they are particular and the management of civil aviation transport personnel is also more stringent. Under normal circumstances, business internal positions management strictly regulates the business and unifies internal work processes. Business-oriented staff is internally trained to make them master higher job skills.

\section{Analysis of Problems in Higher Vocational Civil Aviation Transport Talent Training Education}

\subsection{Lack of scientific curriculum}

Vocational civil aviation institutions must cultivate students' abilities of computer application, spoken English, reading ability and freight knowledge. At present, some higher vocational colleges in the course of setting up the course, focus on the skills training civil aviation enterprises need, focusing on "how to operate" and contempt "why"; at the same time, there is a lack of continuity of systematic air transport curriculum, many students think and solve problems without an overall point of view. In addition, there are too many theoretical courses and training courses are relatively small, resulting in low practical ability of students. Many graduates often do not have any practical experience and cannot meet the needs of society and business.

\subsection{Textbook update is slow}

Past paper ticket is gradually replaced by electronic tickets and traditional ticket counter is gradually replaced by e-commerce network ticketing mode and ticket agent distribution model. Freight forwarding and freight forwarders are moving in a comprehensive information management development. The progress of civil aviation industry reflects the strong demand for new talents in the new era [1]. It is the key to higher vocational training in civil aviation that teaching materials are prepared according to actual needs. However, some teachers do not really recognize the importance of updating textbooks. They still teach in old teaching plans, leading to not advance enough students' learning content and feeling useless in the enterprise.

\subsection{Serious backward teaching mode}

In the new era, there will be new developments. This not only aims at civil aviation enterprises, but also higher vocational civil aviation college and university, who should have the concept of continuous innovation in teaching of civil aviation transportation. At present, higher civil aviation colleges still use basic knowledge and theory - case - internship - thesis teaching mode. Although it can enhance students' theoretical knowledge, it is not conducive to the cultivation of students' innovative abilities. In some extracurricular practice training courses, teachers also lack of comprehensive ability to meet the learning needs of students, reducing the efficiency of the implementation of professional practice courses.

\section{Strategy Analysis of Higher Vocational Civil Aviation Transportation Talents Training}

\subsection{Design talent training programs and teaching curriculum system}

\subsubsection{Talent training program}

Based on the goal of vocational ability training, engineering-learning combination talent training plan is adopted, the vocational standards of future job of students are objects, and integrate the teaching mode of "engineering" and "learning". This is an important program to cultivate talents for civil aviation transport in higher vocational colleges.

Vocational civil aviation transport major teaching curriculum system is determined in accordance with the combination of engineering and training program. In design process, business modules, 
curriculum modules and job tasks modules, curriculum modules and post task modules are included to meet the needs of "Four Major Professional Ability", see Figure 1.

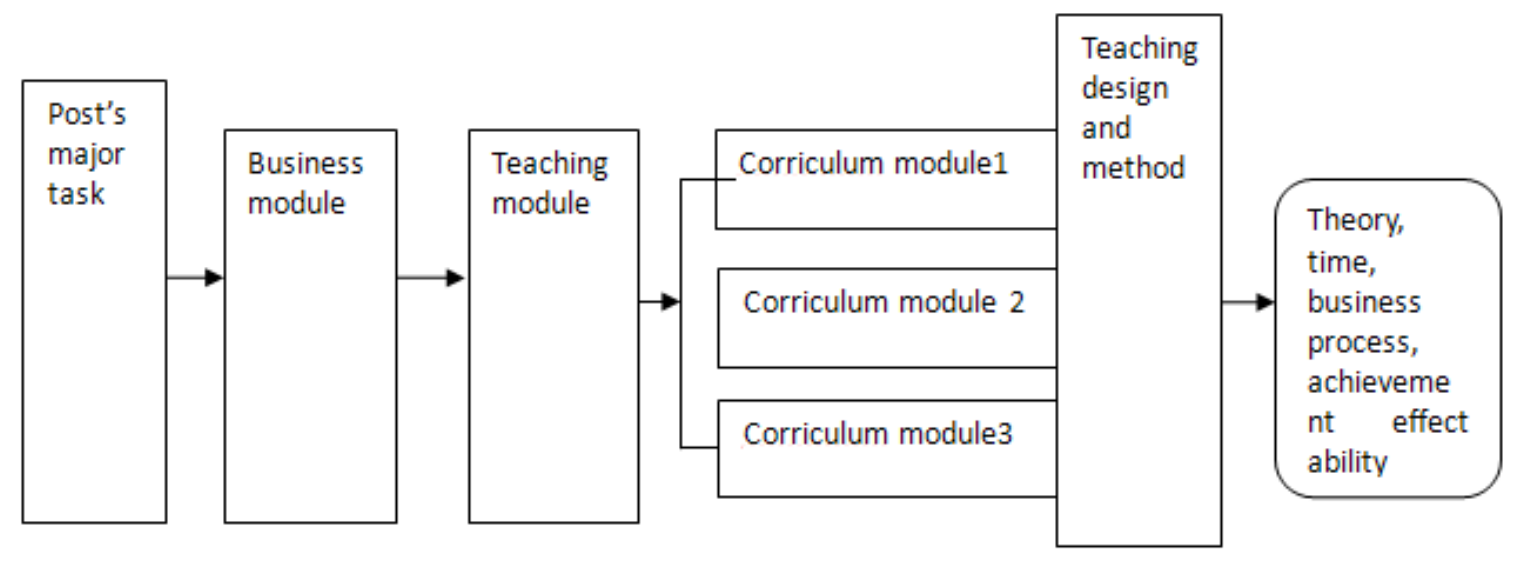

Figure 1 Engineering and learning personnel training program design flow chart

\subsubsection{Teaching curriculum system}

The following principles should be observed when designing a course system:

(1) Break through the past guidance of science-oriented curriculum set by civil aviation transport professionals and make innovations. According to the real demand of cultivating skilled talents in higher vocational education, subject curriculum is replaced by modular curriculum to formulate a more scientific teaching method for students and integrate the teaching concept of "teaching, learning and doing" to ensure the quality of personnel training.

(2) Taking the job assignment of civil aviation transportation manufacturing enterprises as a guide, carry out job classification, and divide business modules in detail according to job principle. For example, civil aviation passenger jobs are divided into ticketing business and aircraft loading business, integrating professional theoretical knowledge, skill training, and optimized teaching process.

(3) Occupation operation is taken as teaching standard and relative training mode is set for each business module, such as the training of civil aviation ticketing business, students need to enhance their computer reservation operation technology.

\subsubsection{Rational planning of the overall teaching plan}

The combination of engineering and learning should ensure that students have sufficient practical time [2]. The requirements for the total number of teaching hours are as follows: the requirement of higher vocational education is that the number of classroom teaching hours should not exceed 1,800 hours. Civil aviation transport major's learning time is 3 years; class hours can be designed for about 1319 hours, 398 class training hours, 990 hours of school hours, and a total of 2707 school hours. For theoretical courses, school training and practice outside the school, the proportion can be set to $49 \%, 15 \%, 36 \%$.

\subsection{B. Strengthen the training of double-qualified teachers and promote teaching methods innovation}

\subsubsection{Training double-qualified teacher}

Dual-qualified teachers are teachers who have both corporate job qualifications and qualifications of the school teachers, and have a certain degree of post work experience. Higher vocational colleges need to increase the introduction and training of double-qualified teachers, and the following training measures can be adopted:

(1) Encourage teachers to work in enterprises. This measure, as a new way to reform teaching mode with the combination of work and study, has obtained the right to go to work for enterprises after obtaining the vocational qualification certificate of enterprise post [3], which can greatly promote the improvement of teachers' comprehensive ability. 
(2) Lead internship and production practice. Teachers lead students in business internships, and actively participate in production practices, and make regular rotation.

(3) Make full use of spare practice and actively participate in teaching practice. Teachers can take full advantage of summer and summer vacation to participate in practical activities. In accordance with the needs of teachers, companies can arrange activities and also promote teachers for on-site research activities.

\subsubsection{Innovation of teaching methods}

In order to realize the integration of "teaching, learning and doing", we should stimulate students' perceptual thinking and rational thinking in teaching activities. Therefore, video technology and video teaching methods can be used. Through video technology [4], civil aviation production situation site video is created and broadcast in business teaching for students to watch, such as customer service approach, flight services, etc., so that students can have immersive feeling through real situation, enhancing thinking ability. In addition, we can adopt teaching methods that enable students to truly participate, that is, situational teaching and role playing to create a real business context for students and give each student a true role so that students can feel deeply and enhance their business sense. For example, design an airport flight delay and customer complaint scenario and allow students to learn more useful knowledge and skills.

\subsection{School training building and practice management outside the school}

\subsubsection{School training design}

First of all, in the process of school training building, we must do the following: civil aviation computer reservation training for the sale of airport business, airport departure training system organized for airport passenger transport, training of dangerous goods identification ability, and training of transport service personnel etiquette and so on. Meet the basic content of student learning, and if the conditions are sufficient, build civil aviation call center [5] to enhance students' business ability. Second, the training efficiency of students in integrated services can be enhanced through various activities. From the perspective of professional ability, objectively analyze the level of professionalism of students so that students can obtain satisfactory professional ability after graduation. Build vocational capacity competition so that students can enhance their enthusiasm through training to continuously enhance their abilities.

\subsubsection{Improve school practice management}

Protocol management or normal management can be adopted. Agreement management is the management of the existing internship base, and achieves the control of the practice base to ensure the rationality of the number of interns by strictly according to the agreement. Normal management, that is, there is an existing agreement whose one-time practice can accommodate more than 50 management base [6-7]. This management mode requires a dedicated teacher participation to get in charge of the entire practice of students. In addition, during on-site teaching management of the practice base, it can communicate well with the enterprise to ensure students' on-the-spot teaching or exams and avoid adverse impact on the operation time of enterprises. Time and content of part-time teachers' lectures are clarified because part-time teachers usually hold positions in enterprises, which can effectively avoid conflict of work arrangements.

\section{Conclusions}

Higher vocational civil aviation transportation undertakes social and business talent source. In face of the development of today's society, vocational colleges must improve the quality of civil aviation transportation professionals to ensure the delivery of a steady flow of high-quality talents to enterprises [8]. Based on this, this paper puts forward some opinions on personnel training, curriculum establishment, teacher team building, and practical training in school and practice management outside school. It holds that current professional civil aviation transportation major must integrate curriculum resource setting, giving students full practice opportunity. By enhancing 
teachers' teaching ability, finally innovate more advanced teaching methods, bring into full play the role of combining teaching with work and learning and achieve a win-win situation for schools and enterprises.

\section{References}

[1] Zhou Limin, Pan Guoqiang. Analysis on the Development of Civil Aviation Industry in Zhejiang Province and Training Talents for Air Transportation in Higher Vocational Education [J]. Journal of Zhejiang Traffic Polytechnic, 2017, 18 (3): 69-74.

[2] Li Furong. Construction and Design of Curriculum System based on Work Process of Civil Aviation Transportation Specialty in Higher Vocational Education ---- A Case Study of Changsha Aviation Polytechnic [J]. Knowledge Economy, 2017 (14): 147-148.

[3] Lu Zhu. Vocational aviation transport major course system architecture based on the post occupational ability [J]. Vocational Education, 2015 (12): 10-12.

[4] Li Gang. Innovation of Accounting Professionals Training Mode in Higher Vocational Colleges based on Industry Characteristics ---- A Case Study of Accounting Major in Guangzhou Civil Aviation Technical College [J]. Business Accounting, 2017 (21): 123-125.

[5] Zhao XiaoShuo. Exploration of Practical Teaching Reform in Higher Vocational Civil Aviation Transportation under the Combination of Industry and Learning ---- A Case Study of Sanya Aviation Tourism Vocational College [J]. China Training, 2017 (8): 157-157.

[6] Liu Yang, Chen Bo. On personnel training of civil aviation higher vocational education based on China's civil aviation development planning [J]. Career Space, 2017 (1): 66-69.

[7] Li Shaolin, Wu Wanmin. A Practical Exploration of the Training Mode of Internationalized Skill Talents in Higher Vocational Colleges ---- A Case Study of Guangzhou Civil Aviation Technical College [J]. China Training, 2016 (6): 16-17.

[8] Qiu Hongwei. Research on the Practice of "My Chinese Dream" in Higher Vocational Colleges ---- A Case Study of Cultivation of Professionalism in Guangzhou Civil Aviation Technical College [J]. Lanzhou Petrochemical Technology Institute, 2016, 16 (2)): 47-51. 